\title{
Nitrogen Availability and Uptake by Sugarbeet in Years Following a Manure Application
}

\author{
Rodrick D. Lentz and Gary A. Lehrsch \\ North West Irrigation and Soils Research Laboratory, USDA-ARS, 3793 N 3600 W, Kimberly, ID, 83341-5076, USA \\ Correspondence should be addressed to Rodrick D. Lentz, rick.lentz@ars.usda.gov
}

Received 16 November 2011; Accepted 20 February 2012

Academic Editor: Mark Reiter

Copyright ( $\odot 2012$ R. D. Lentz and G. A. Lehrsch. This is an open access article distributed under the Creative Commons Attribution License, which permits unrestricted use, distribution, and reproduction in any medium, provided the original work is properly cited.

\begin{abstract}
The use of solid dairy manure for sugarbeet production is problematic because beet yield and quality are sensitive to deficiencies or excesses in soil $\mathrm{N}$, and soil $\mathrm{N}$ availability from manure varies substantially depending on the year of application. Experimental treatments included combinations of two manure rates $\left(0.33\right.$ and $0.97 \mathrm{Mg}$ total $\left.\mathrm{N} \mathrm{ha}^{-1}\right)$ and three application times, and nonmanure treatments (control and urea fertilizer). We measured soil net $\mathrm{N}$ mineralization and biomass, $\mathrm{N}$ uptake, and yields for sprinkler-irrigated sugarbeet. On average, the 1-year-old, low-rate manure, and 1- and 2-year-old, high-rate manure treatments produced 1.2-fold greater yields, 1.1-fold greater estimated recoverable sugar, and 1.5-fold greater gross margins than that of fertilizer alone. As a group the 1-year-old, low-rate manure, and 2- and 3-year-old, high-rate-manure treatments produced similar cumulative net $\mathrm{N}$ mineralization as urea fertilizer; whereas the 1-year-old, high-rate manure treatment provided nearly 1.5 -fold more $\mathrm{N}$ than either group. With appropriate manure application rates and attention to residual $\mathrm{N}$ and timing of sugarbeet planting, growers can best exploit the $\mathrm{N}$ mineralized from manure, while simultaneously maximizing sugar yields and profits.
\end{abstract}

\section{Introduction}

An estimated 20 million Mg manure is produced annually by the 9-million-cow US dairy herd. The regional dairy center in southern Idaho comprises $5.6 \%$ of the US total dairy herd and produces approximately 1.11 million $\mathrm{Mg}$ manure annually. In Idaho, much of the dairy manure is soil applied to supply crop nutrients and as a means of rebuilding soil organic carbon. The latter is particularly important for eroded soils, which are common in this historically furrow irrigated region [1]. To maximize their use of manure and minimize losses of nitrogen $(\mathrm{N})$ to the environment, growers need to know how much $\mathrm{N}$ becomes available to crops from manure applications [2]. In addition, as competition increases for cropland in the region, farmers who rent acreage can expand the pool of land available to them if they are willing to utilize manured ground.

This is particularly important for sugarbeet (Beta vulgaris L.) growers because yield and beet quality parameters, sugar, and brei nitrate concentration are sensitive to both insufficient $\mathrm{N}[3,4]$ and excess soil $\mathrm{N}[5,6]$. In addition, sugarbeet tends to incorporate soil residual $\mathrm{N}$ preferentially over fertilizer N, that is, sugarbeet will utilize more soil residual $\mathrm{N}$ and less applied fertilizer $\mathrm{N}$ than corn or tomato crops [7]. Applying excess $\mathrm{N}$ fertilizer early in the season or applying an optimal $\mathrm{N}$ application after June can divert photosynthate sugars normally used for beet root growth and sucrose accumulation to excess top growth [8]. By contrast, multiple small feedings of $\mathrm{N}$ to the sugarbeet from May through July can increase sucrose accumulation in roots [9]. Early research showed a positive influence of manure on beet yield and sucrose concentration $[3,5]$. Still, planting sugarbeet in recently manured fields is not always recommended because $\mathrm{N}$ availability from the manure is not well quantified and is believed to occur too late in the season to improve yield and quality [10]. However, Lentz et al. [11] reported that (1) peak net $\mathrm{N}$ mineralization in manure-amended, irrigated soils coincided with maximum $\mathrm{N}$ uptake by beet and (2) first-year manure applications $\leq 20 \mathrm{Mg} \mathrm{ha}^{-1}$ (dry wt.) had no significant adverse effect on beet yield or quality.

Much of the $\mathrm{N}$ in dairy manure is in the organic form and only becomes available for uptake by crops via the timedependent microbial-mediated process of mineralization. 
Several studies have examined crop $\mathrm{N}$ uptake after multiple dairy manure applications, for barley (Hordeum vulgare L.) [12-14], corn (Zea mays L.) [15], wheat (Triticum aestivum L.) [16], and orchard grass (Dactylis glomerata L.) [17], or in the first year after a single manure application, for corn $[18,19]$, sugarbeet $[11]$, and orchard grass (Dactylis glomerata L.) [17]. Relative to the total $\mathrm{N}$ applied in dairy manure, $\mathrm{N}$ recovery by corn, sugarbeet, and orchard grass in the first year after a single application ranged from -5 to $40 \%$ and averaged 21\% [11, 17-19]. Crop $\mathrm{N}$ uptake from dairy manure amendments is influenced by type of crop [15], manure characteristics [20], organic amendment history [21], soil and location factors $[18,22,23]$, application timing [12], and cropping management [24].

Far fewer studies have assessed $\mathrm{N}$ uptake by crops two and three or more years after a single manure application. For corn, the crop $\mathrm{N}$ recovery in the 2 nd year after manure application was reported to be $9 \%$ by Klausner et al. [25], 8 to $15 \%$ by Ma et al. [15], and $15 \%$ by Eghball and Power [19], and $\mathrm{N}$ recovery for corn in years 3 through 4 was reported by Klausner et al. [25], being 2 or 3\%. Similar studies for sugarbeet are lacking. One of the difficulties encountered when measuring crop $\mathrm{N}$ recovery from a manure application in successive years is the obfuscation caused by climatic variations between years [11]. Our objective was to (1) determine the effect of a single dairy manure application on sugarbeet yields and quality, $\mathrm{N}$ uptake, and $\mathrm{N}$ recovery for one, two, and three years after applying manure to a calcareous, irrigated, southern Idaho soil, and (2) employ an experimental approach that would reduce the confounding effects of climate between years.

\section{Materials and Methods}

We conducted the experiment at a site located $1.7 \mathrm{~km}$ southwest of Kimberly, ID (42E 31.12' N, 114E $22.47^{\prime}$ W, elevation of $1190 \mathrm{~m}$ ). The field plots were prepared in Portneuf silt loam soils (coarse silty, mixed, superactive, mesic Durinodic Xeric Haplocalcid). The experimental site had a history of maznure applications, receiving 40 to $75 \mathrm{Mg} \mathrm{ha}^{-1}$ dry wt. every 3 yr between 1969 and 1986. In 1991 the uppermost $0.3 \mathrm{~m}$ (Ap horizon) of the Portneuf silt loam's profile was removed to expose the underlying Bk horizon and simulate an eroded profile [26]. For noneroded soil, the Ap horizon was left undisturbed. The site last received manure in 1994, $10 \mathrm{yrs}$ before field plot preparations began for the current study. The eroded Portneuf soil profile is deep and calcareous, with textures ranging from silt loam to very fine sandy loam. Its surface soil $(0$ to $15 \mathrm{~cm})$, that is, the $\mathrm{Bk}$ horizon, is a silt loam and contains on average $184 \mathrm{~g} \mathrm{~kg}^{-1}$ clay, $609 \mathrm{~g} \mathrm{~kg}^{-1}$ silt, $207 \mathrm{~g} \mathrm{~kg}^{-1}$ sand, has a $\mathrm{pH}$ of $7.8\left(\mathrm{H}_{2} \mathrm{O}\right.$ saturated paste), electrical conductivity (EC) of $0.08 \mathrm{~S} \mathrm{~m}^{-1}$, and includes $4.1 \mathrm{mg} \mathrm{kg}^{-1}$ organic carbon, and $221 \mathrm{mg} \mathrm{kg}^{-1}$ calcium carbonate equivalent. A silica and calcium carbonatecemented horizon (20-60\% cementation) occurs between depths of 33 to $130 \mathrm{~cm}$ in the eroded Portneuf. The soil has a mean cation exchange capacity of $190 \mathrm{mmol}_{\mathrm{c}} \mathrm{kg}^{-1}$ and exchangeable sodium percentage of 1.5 .
2.1. Experimental Design. Comparing sugarbeet yield and $\mathrm{N}$ uptake from a soil in years following a one-time manure application is problematic. Comparisons between annual sugarbeet measurements would be influenced not only by the treatment, but also by pest problems related to the continuous beet plantings and by climatic factors, which vary from year to year. To limit the effect of these confounding factors, we applied manure treatments at a $1 \mathrm{x}$ rate (average bulk application rate of $21.7 \mathrm{Mgha}^{-1}$ dry wt. or $0.31 \mathrm{Mg}$ total $\mathrm{Nha}^{-1}$ ), and a nominal $3 \mathrm{x}$ rate (average bulk application of $68.9 \mathrm{Mg} \mathrm{ha}^{-1}$ dry wt. or $0.97 \mathrm{Mg}$ total $\mathrm{N} \mathrm{ha}^{-1}$ ) once only to a different set of field plots in the fall of each year 2004, 2005, and 2006. Thus, when sugarbeet was grown in 2007, the field plots included a set of two manure-rate treatments that were 1,2 , or 3 years old and were exposed to the same climatic conditions.

The experimental design was a randomized complete block with nine treatments and 4 replicates (Table 1). The experiment included the six manure treatments, with a manure-1x (m1) and manure-3x (m3) applied once to different plots of "eroded" Portneuf silt loam in 2004, 2005, and 2006. Three no-manure treatments were also included, urea fertilized (Fert) and control (no fertilizer or manure) treatments on eroded Portneuf soil, and a fertilized (urea) treatment on noneroded Portneuf soil (NE-Fert). No inorganic $\mathrm{N}$ fertilizer was applied to manure treatments. The Fert and NE-Fert treatments received $135 \mathrm{~kg} \mathrm{~N} \mathrm{ha}^{-1}$ as urea- $\mathrm{N}$, based on a sugarbeet yield goal of $63 \mathrm{Mgha}^{-1}$ [27] and a spring preplant soil test, which determined residual inorganic $\mathrm{N}$ present in the root zone $(0-90 \mathrm{~cm})$. The manure-1x application rate was a commonly applied rate in the region. At application time, we estimated the $\mathrm{m} 1$ manure would provide an average $107 \mathrm{~kg} \mathrm{Nha}^{-1}$ to crops in the first year after application, based upon earlier reports that $32 \%$ of total manure $\mathrm{N}$ was available to crops in the first year [28]. Since a soil test indicated that no P or K fertilizer was needed on our site, we applied none. Plots were $9.1 \mathrm{~m}$ wide $\times 21.3 \mathrm{~m}$ long and accommodated 16 rows of beets.

For each year that manure treatments were applied, we obtained solid dairy cattle (Bos species) manure that had been stockpiled at a local dairy through the summer. The manure's average total $\mathrm{C}$ concentration (standard error) was $217 \mathrm{~g} \mathrm{~kg}^{-1}\left(58 \mathrm{~g} \mathrm{~kg}^{-1}\right)$, total $\mathrm{N}$ was $14.1 \mathrm{~g} \mathrm{~kg}^{-1}\left(2.6 \mathrm{~g} \mathrm{~kg}^{-1}\right)$, and $\mathrm{C}: \mathrm{N}$ ratio was $15.9(1.5)$.

2.2. Field Operations. Manure was applied to designated plots on 18 Nov. 2004, 22 Dec. 2005, and 19 Oct. 2006 using a commercial spreader truck equipped with rooster-comb beaters. Two to four $0.15 \mathrm{~m}^{2}$ trays were randomly placed in each plot prior to spreading to quantify application rate. The manure collected in each tray was weighed, mixed, subsampled for moisture, $\mathrm{C}$, and $\mathrm{N}$ analyses, and then returned to the soil surface from which it had been collected. The field was disked to a depth of $0.1 \mathrm{~m}$ within 48 hours of manure application. Plots were not fertilized in 2005 prior to planting spring barley. Barley was harvested in mid-July 2005. In fall 2005 prior to manure application, surface residue was burned to destroy weedy growth that had occurred after harvest. 
TABLE 1: Description of treatments.

\begin{tabular}{|c|c|c|c|c|c|c|}
\hline Treatment name & Treatment ID & Soil type & Added N source & $\begin{array}{l}\text { Bulk applic. rate, dry wt. } \\
\qquad \mathrm{Mg} \mathrm{ha}^{-1}\end{array}$ & $\begin{array}{c}\text { Year of } \\
\text { application }^{\dagger}\end{array}$ & $\begin{array}{c}\text { Treatment age }(y) \\
\text { at time of } \\
\text { measurement }\end{array}$ \\
\hline Noneroded fertilizer & NE-Fert & Noneroded & Urea & 0.29 & Each year & 1 \\
\hline Control & Control & Eroded & None & 0 & N/A & 1 \\
\hline Fertilizer & Fert & Eroded & Urea & 0.29 & Each year & 1 \\
\hline \multicolumn{7}{|l|}{ Manure-1x } \\
\hline 2006 & m1-y1 & Eroded & Dairy manure & 17.4 & 2006 & 1 \\
\hline 2005 & m1-y2 & Eroded & Dairy manure & 32.5 & 2005 & 2 \\
\hline 2004 & m1-y3 & Eroded & Dairy manure & 23.0 & 2004 & 3 \\
\hline \multicolumn{7}{|l|}{ Manure-3x } \\
\hline 2006 & m3-y1 & Eroded & Dairy manure & 56.7 & 2006 & 1 \\
\hline 2005 & m3-y2 & Eroded & Dairy manure & 78.4 & 2005 & 2 \\
\hline 2004 & m3-y3 & Eroded & Dairy manure & 71.7 & 2004 & 3 \\
\hline
\end{tabular}

${ }^{\dagger}$ All fertilizer was applied in spring 2007 while all manure was applied in fall of the year shown.

In March 2006 soil samples were taken from plots at 0-to$30 \mathrm{~cm}$ and 30-to- $60 \mathrm{~cm}$ depths and analyzed for soil N, P, and $\mathrm{K}$ (described below). Levels of $\mathrm{P}$ and $\mathrm{K}$ in the soils were adequate for small grain. On 13 Apr. 2006 the Fert and NEFert treatments received $134 \mathrm{~kg} \mathrm{~N} \mathrm{ha}^{-1}$ as urea via hand-held spreader, while the control and manure plots received none. The field was disked to $0.1 \mathrm{~m}$ depth and roller-harrowed prior to planting barley in late April 2006. Barley residue and volunteer growth was burned on 13 Oct. 2006 before manure was applied to the designated plots.

On 15 Mar. 2007 soil samples were collected from plots in $30 \mathrm{~cm}$ increments down to $90 \mathrm{~cm}$. We applied urea to the Fert and NE-Fert treatments and immediately incorporated the material with a roller harrow. Sugarbeet seed was planted (cv. BETA 4023R) on 20 Apr. 2007 in rows $0.56 \mathrm{~m}$ apart, with an in-row spacing of $55 \mathrm{~mm}$ and later thinned (30 May 2007 ) to a population of 117,000 plants $^{-1} \mathrm{~h}^{-1}$ (manufacturer or trade names are included for the readers' benefit. The USDA-ARS neither endorses nor recommends such products). Insect control was accomplished using a Poncho seed treatment (CropScience LP, Research Triangle Park, NC, USA). Standard commercial procedures were used to control weeds and diseases. A single cultivation was performed on 26 June 2007. Irrigation through the growing season was supplied via sprinkler to meet the crop's evapotranspiration requirements. The beet crop was harvested on 10 Oct. 2007. Meteorological data required to calculate crop evapotranspiration (ET) were acquired from a weather station located $5.6 \mathrm{~km}$ northeast of the experimental plots. A rain gauge located near the field plot measured growing season precipitation. Crop ET was estimated from the maximum reference ET calculated using the Kimberly-Penman ET model [29], adjusted with the appropriate daily crop coefficient. Mean monthly air temperature, and total monthly precipitation, and irrigation during the 36-month study (including the plot preparation period, Fall, 2004 through 2006, and 2007 growing season) are reported in Figure 1.

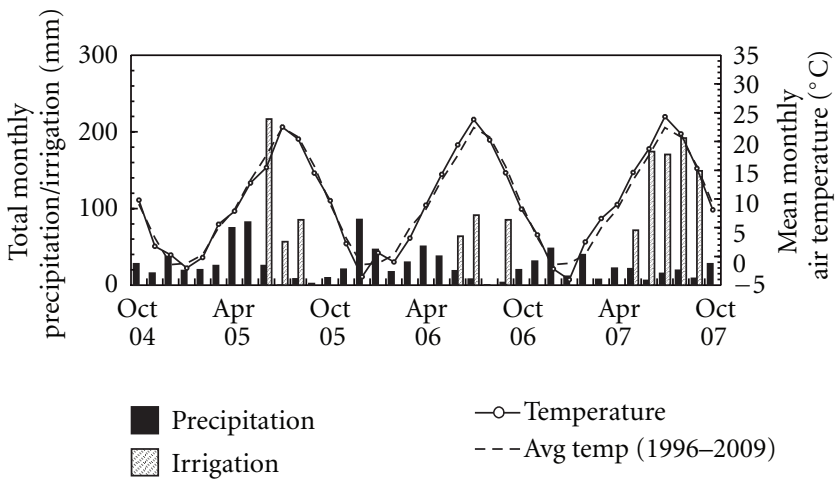

FIGURE 1: Total monthly precipitation and irrigation amounts, and mean monthly air temperature at the study site from fall 2004, when the first manure treatment was applied, through the 2007 growing season, when sugarbeet was planted on the experimental plots.

2.3. Sampling and Analyses. We measured $\mathrm{N}$ uptake in sugarbeet four times (1 June, 13 July, 20 Aug., and 27 Sep.) during the 2007 growing season by sampling total biomass of plant tops (aboveground tissue) and roots from $2 \mathrm{~m}$ of two adjacent rows ( $4 \mathrm{~m}$ total). The shredded sugarbeet roots and other aboveground plant tissue were dried at $65^{\circ} \mathrm{C}$ for dry matter determination. After grinding the dried tissue in a Thomas Wiley mill (Swedesboro, NJ) to pass an $865 \mu \mathrm{m}$ screen, its total-N concentration was determined on a Thermo-Finnigan FlashEA1112 CNS analyzer (CE Elantech Inc., Lakewood, NJ, USA).

Sugarbeet yields were determined on 10 Oct. 2007 from two samples in each plot, each consisting of two adjacent $7.6 \mathrm{~m}$ long rows. Beet root subsamples collected for each of the two plot samples were analyzed for soil tare, as well as quality factors such as brei nitrate, brei conductivity, and sugar concentration, by the Amalgamated Sugar Company laboratory (Paul, ID, USA). Plot values were computed as 
the arithmetic mean of the two samples. The projected gross margin for each plot was computed as gross revenue minus operating costs. The gross revenue was calculated as the product of beet yield (tons, wet wt.) and the 2007 grower beet payment, which varied from $\$ 33.47$ to $\$ 39.23$ per ton of beets (wet wt.) depending on beet sugar percentage. Operating costs [30] were assumed equal for all treatments except for differences related to fertilizer and manure application. Manure costs included only transport and spreading fees based on a $3.2 \mathrm{~km}$ one-way haul distance. Manure application costs were amortized across two years, hence the manure cost in the 3rd year after application was zero. Costs associated with annual fertilizer treatments included the price of product and its application.

A buried bag technique [31] was used to measure net $\mathrm{N}$ mineralization in plot soils during the 2007 growing season. Briefly, three $5.7 \mathrm{~cm}$ diameter soil cores, 0-to- $30 \mathrm{~cm}$ deep were collected on 25 Apr. 2007 in each plot (one from three of the plot's four quadrants), composited, and passed through a $0.4 \mathrm{~cm}$ screen. A subsample of the composited soil was collected to determine baseline (or initial) inorganic $\mathrm{N}$ and soil water content. The remaining soil was placed in $10 \mu \mathrm{m}$ thick, $5 \mathrm{~cm}$ diam. polyethylene tubes sealed on one end. After being filled, the tubes were sealed on the remaining end, resulting in three $30 \mathrm{~cm}$ long soil columns that were inserted into the sample holes created previously. The bag's polyethylene film was only slightly permeable to water vapor but allowed good gas exchange between the enclosed soil and that surrounding it $[31,32]$. A single bag was pulled from each plot on 15 June, 1 Aug., and 2 Oct. 2007. The net $\mathrm{N}$ mineralization during the period between burial and retrieval was calculated by subtracting the baseline inorganic $\mathrm{N}$ concentration $\left(\mathrm{NO}_{3}-\mathrm{N}+\right.$ $\mathrm{NH}_{4}-\mathrm{N}$ ) of the initial soil (collected 25 Apr.) from that of the retrieved bag. A positive difference indicated net $\mathrm{N}$ mineralization, while a negative value indicated net $\mathrm{N}$ immobilization during the period. We measured net $\mathrm{N}$ mineralization using buried bags for 25 Apr. to 15 June, 15 June to 1 Aug., and 1 Aug. to 2 Oct. The latter two period values were computed by difference relative to the previously retrieved buried bag sample. In addition, we estimated the net $\mathrm{N}$ mineralization in the not-yet-planted plots from 15 Mar. to 25 Apr. as the difference in soil inorganic $N$ concentration $(0-30 \mathrm{~cm})$ between the two dates. We reported the net $\mathrm{N}$ mineralized as $\mathrm{mg} \mathrm{N} \mathrm{kg}^{-1}$ soil. Cumulative available soil $\mathrm{N}$ (0-to- $30 \mathrm{~cm}$ depth) during the growing season was computed as the sum of the initial soil inorganic N present on 15 Mar., added fertilizer $\mathrm{N}$ (if any), and net $\mathrm{N}$ mineralized across the four periods.

The March 2006 and 2007 field soil samples and buried bag soil samples were air dried at $35^{\circ} \mathrm{C}$ and ground to pass a $2 \mathrm{~mm}$ screen. Soil $\mathrm{N}$ was extracted using a $2 \mathrm{M} \mathrm{KCl}$ solution. Within $6 \mathrm{~h}$ of extraction, the $\mathrm{NO}_{3}-\mathrm{N}$ concentration in each extract was determined using an automated flow injection analyzer (Lachat Instruments, Loveland, CO, USA) after cadmium reduction (Method 12-107-04-1-B) while $\mathrm{NH}_{4}-\mathrm{N}$ concentration was determined using a salicylate-hypochlorite method (Method 12-107-06-2-A). The soil's inorganic N concentration was calculated as the sum of the $\mathrm{NO}_{3}-\mathrm{N}$ and $\mathrm{NH}_{4}-\mathrm{N}$ concentrations ( $\mathrm{mg} \mathrm{N} \mathrm{kg}^{-1}$ of dry soil). Bicarbonate extractable P [33] and exchangeable K [34] (except without the addition of charcoal) were determined on field soil samples using ICP-OES. Manure $\mathrm{C}$ and $\mathrm{N}$ concentrations were determined on a freeze-dried sample with the CNS analyzer described above.

2.4. Statistical Analysis. Crop yield, biomass, $\mathrm{N}$ uptake, and quality factors for sugarbeet (brei nitrate, brei conductivity) were examined separately for each reporting interval via analysis of variance (ANOVA), PROC Mixed [35]. The statistical model included treatment as the fixed effect and block as the random effect. Treatment means were separated using the Tukey option [35]. We also included several single-degree-offreedom orthogonal contrasts in the analysis. These included up to five class comparisons, where a class represents a combination of treatments: (1) no-manure versus manure treatments, where the no-manure class is control + Fert + NE-Fert and manure is $\mathrm{m} 1+\mathrm{m} 3$; (2) manure- $1 \mathrm{x}$ versus manure- $3 \mathrm{x}$ treatments, averaged across all years; (3) manure-1x versus manure-3x treatments for years 2 and 3 only; (4) manure only treatments $(\mathrm{m} 1+\mathrm{m} 3)$ in year- 1 versus years 2 and 3; (5) $\mathrm{m} 1-\mathrm{y} 1+\mathrm{m} 3-\mathrm{y} 1+\mathrm{m} 3-\mathrm{y} 2$ versus NE-Fert + Fert. The last contrast (number 5) tested the hypothesis that, relative to fertilizer applications, the effect of manure on the crop was influenced by the interaction between the factors, manure rate and age of application. Since the manure- $1 \mathrm{x}$ added less $\mathrm{C}$ and $\mathrm{N}$ to the soil, its influence on the crop would diminish more rapidly than the manure-3x applications. All analyses were conducted using a $P=0.05$ significance level. An identical statistical approach was used to analyze treatment effects on cumulative available soil $\mathrm{N}$.

Since the experiment was conducted at a single location, findings pertain principally to that location. With judicious foresight, however, inferences made and conclusions drawn may apply to other locations with similar climatic conditions and crop management practices.

\section{Results and Discussion}

Meteorological data presented in Figure 1 portray the climatic conditions that prevailed during the years when the experimental plots were being developed and for 2007, the year that sugarbeet was grown on the site. The 2007 growing season was warmer than average, specifically during the February-July period, which was on average $1.5^{\circ} \mathrm{C}$ warmer than the 1996-to-2009 mean. The plots received $175 \mathrm{~mm}$ of annual rainfall in 2007, or 70\% of the 1996-to-2009 mean value. The increased early-summer heat units coupled with abundant irrigation water supplies and the delay of hard frost until after October (instead of late September) contributed to near optimal 2007 sugarbeet yields in southern Idaho [36].

3.1. Sugarbeet Biomass and N Uptake. Several treatment effects were significant for the sugarbeet cumulative biomass (Table 2) and $\mathrm{N}$ uptake (Table 3) within each measurement period. The contrast tests identified several relationships with respect to treatment classes. First, the no-manure and manure treatments on the whole produced similar cumulative biomass and $\mathrm{N}$ uptake in sugarbeet tops, roots, and whole 
TABLE 2: The influence of treatment on the total cumulative biomass for 2007 sugarbeet plant components. Table gives $P$ values for treatment effects, and single-degree-of-freedom orthogonal comparisons derived from an analysis of variance.

\begin{tabular}{|c|c|c|c|c|c|c|c|c|c|c|c|c|}
\hline \multirow{4}{*}{ Source of variation } & \multicolumn{12}{|c|}{ Accumulated sugarbeet biomass } \\
\hline & \multicolumn{4}{|c|}{ Tops } & \multicolumn{4}{|c|}{ Roots } & \multicolumn{4}{|c|}{ Whole plant } \\
\hline & 1 & 13 & 20 & 27 & 1 & 13 & 20 & 27 & 1 & 13 & 20 & 27 \\
\hline & \multicolumn{12}{|c|}{$P$ values } \\
\hline Treatment (TRT) & $* *$ & $* * *$ & $* * *$ & $* *$ & 0.36 & $* *$ & $* * *$ & $* *$ & 0.02 & $* * *$ & $* * *$ & $* * *$ \\
\hline \multicolumn{13}{|l|}{ Orthogonal contrasts $^{\dagger}$} \\
\hline No manure versus manure & 0.64 & 0.26 & 0.7 & 0.5 & 0.9 & 0.6 & 0.8 & 0.25 & 0.7 & 0.4 & 0.9 & 0.23 \\
\hline Man: $\mathrm{m} 1$ versus $\mathrm{m} 3$ & $* *$ & $* *$ & $* * *$ & 0.06 & $* *$ & 0.07 & $* * *$ & 0.13 & $* *$ & $*$ & $* * *$ & $*$ \\
\hline Man: y1 versus y2 \& y3 & 0.9 & $* * *$ & $* *$ & 0.29 & 0.82 & $* *$ & $* *$ & $*$ & 0.9 & $* * *$ & $* *$ & * \\
\hline Man y2 \& y3: $m 1$ versus $m 3$ & $* *$ & $* *$ & $* * *$ & $*$ & $* *$ & $*$ & $* * *$ & $*$ & $* *$ & $* *$ & $* * *$ & $* *$ \\
\hline
\end{tabular}

${ }^{\dagger}$ No manure: NEFert + control + Fert; Man: manure $=\mathrm{m} 1+\mathrm{m} 3$ where $\mathrm{m} 1$ : manure-1x; $\mathrm{m} 3$ : manure-3x; y1, y2, y3: fall manure applied 1, 2, and 3 years in the past, respectively.

${ }^{*} P<0.05,{ }^{* *} P<0.01,{ }^{* * *} P<0.001$.

TABle 3: The influence of treatment on N uptake in 2007 sugarbeet plant components. Table gives $P$ values for treatment effects, and singledegree-of-freedom orthogonal comparisons derived from an analysis of variance.

\begin{tabular}{|c|c|c|c|c|c|c|c|c|c|c|c|c|}
\hline \multirow{4}{*}{ Source of variation } & \multicolumn{12}{|c|}{$\mathrm{N}$ uptake by beet biomass components } \\
\hline & \multicolumn{4}{|c|}{ Tops } & \multicolumn{4}{|c|}{ Roots } & \multicolumn{4}{|c|}{ Whole plant } \\
\hline & $\begin{array}{c}1 \\
\text { June }\end{array}$ & $\begin{array}{c}13 \\
\text { July }\end{array}$ & $\begin{array}{c}20 \\
\text { Aug }\end{array}$ & $\begin{array}{c}27 \\
\text { Sept }\end{array}$ & $\begin{array}{c}1 \\
\text { June }\end{array}$ & $\begin{array}{c}13 \\
\text { July }\end{array}$ & $\begin{array}{c}20 \\
\text { Aug }\end{array}$ & $\begin{array}{c}27 \\
\text { Sept }\end{array}$ & $\begin{array}{c}1 \\
\text { June }\end{array}$ & $\begin{array}{c}13 \\
\text { July }\end{array}$ & $\begin{array}{c}20 \\
\text { Aug }\end{array}$ & $\begin{array}{c}27 \\
\text { Sept }\end{array}$ \\
\hline & \multicolumn{12}{|c|}{$P$ values } \\
\hline Treatment (TRT) & $*$ & $* * *$ & $* * *$ & $* * *$ & $*$ & $* *$ & $* * *$ & $* * *$ & * & $* * *$ & $* * *$ & $* * *$ \\
\hline \multicolumn{13}{|l|}{ Orthogonal contrasts $^{\dagger}$} \\
\hline No manure versus manure & 0.26 & 0.25 & 0.78 & 0.52 & 0.38 & 0.35 & 0.75 & 0.7 & 0.65 & 0.26 & 0.9 & 0.6 \\
\hline Man- $1 \mathrm{x}$ versus Man-3x & $* * *$ & $*$ & $* * *$ & * & $* *$ & 0.08 & $* * *$ & $* *$ & $* * *$ & $*$ & $* * *$ & * \\
\hline Man: y1 versus y2 \& y3 & 0.9 & $* * *$ & $*$ & 0.15 & 0.87 & $* * *$ & $* *$ & 0.11 & 0.9 & $* * *$ & $*$ & 0.09 \\
\hline Man y2 \& y3: $\mathrm{m} 1$ versus $\mathrm{m} 3$ & $* *$ & $* *$ & $* * *$ & $*$ & $*$ & 0.06 & $* * *$ & $* *$ & $* *$ & $* *$ & $* * *$ & $* *$ \\
\hline
\end{tabular}

${ }^{\dagger}$ No manure: NEFert + control + Fert; Man: manure $=\mathrm{m} 1+\mathrm{m} 3$ where $\mathrm{m} 1$ : manure-1x; m3: manure-3x; $y 1, y 2, \mathrm{y} 3$ : fall manure applied 1, 2, and 3 years in the past, respectively.

${ }^{*} P<0.05,{ }^{* *} P<0.01,{ }^{* * *} P<0.001$.

plants. This result was partly due to substantial variability among treatment responses within each class, for example, the control treatment values were about half those of other no-manure treatments, and the m1-y3 values were about half that of other manure treatments (Table 4). However, the result shown in Table 3 suggests that no-manure treatments provided similar quantities of soil $\mathrm{N}$ to sugarbeet on average as did the manure treatments. As a consequence, seasonlong, total biomass production, and $\mathrm{N}$ uptake were similar between the groups (Table 4). See the discussion later in this section.

Second, compared to the manure- $1 \mathrm{x}$ treatments, the manure- $3 \mathrm{x}$ in general resulted in $1.12 \mathrm{x}$ greater season-long cumulative biomass production and $1.37 \mathrm{x}$ greater $\mathrm{N}$ uptake (Table 4). In addition, the relative difference between manure- $3 \mathrm{x}$ and manure-1x responses was greater in the 2 nd and 3rd years after manure application (i.e., comparing results of the $\mathrm{m} 1$ versus $\mathrm{m} 3$ contrast in $\mathrm{y} 2$, y3 with that of the $\mathrm{m} 1$ versus $\mathrm{m} 3$ contrast averaged across all years in Table 4). The disproportionately smaller increase in both biomass and $\mathrm{N}$ uptake in response to a tripling of the manure rate indicated that the manure-3x treatment supplied excess $\mathrm{N}$, and/or crop utilization of manure $\mathrm{N}$ decreased with increasing manure application [37]. As time since application increased (comparing the $\mathrm{m} 1$ versus $\mathrm{m} 3$ contrast in $\mathrm{y} 2$, $\mathrm{y} 3)$, the $\mathrm{N}$ supplied by manure- $1 \mathrm{x}$ apparently was less able to support beet growth than the manure- $3 \mathrm{x}$, causing a greater difference in biomass production and $\mathrm{N}$ uptake between the manure rate classes.

Third, the year of manure application affected total sugarbeet biomass and $\mathrm{N}$ uptake more during the early-June to mid-July period than at season's end (Tables 2 and 3). By 13 July 2007 the y1 manure treatments produced $1.4 x$ greater sugarbeet biomass with $1.7 \mathrm{x}$ greater $\mathrm{N}$ uptake than the average for $\mathrm{y} 2$ and $\mathrm{y} 3$ manure treatments (Table 4 ). These disparities declined from that date onward. Thus by season's end, the sugarbeet in 2-year-old and 3-year-old manure plots had largely caught up to those of the 1-year-old manure treatments, such that differences were no longer significant. Thus yl manure treatments generally provided greater 
TABLE 4: Accumulated total biomass and $\mathrm{N}$ uptake in sugarbeet (tops and roots) at four times during the 2007 growing season.

\begin{tabular}{|c|c|c|c|c|c|c|c|c|}
\hline \multirow{3}{*}{ Treatment $^{\dagger}$} & \multicolumn{4}{|c|}{ Biomass } & \multicolumn{4}{|c|}{$\mathrm{N}$ uptake } \\
\hline & 1 June & 13 July & 20 Aug & 27 Sept & 1 June & 13 July & 20 Aug & 27 Sept \\
\hline & \multicolumn{4}{|c|}{$\mathrm{Mg} \mathrm{ha}^{-1}$ (dry wt.) } & \multicolumn{4}{|c|}{$\mathrm{Kg} \mathrm{ha}^{-1}$} \\
\hline \multicolumn{9}{|l|}{ No manure } \\
\hline NE-Fert & $0.15 \mathrm{a}^{\ddagger}$ & $7.3 \mathrm{ab}$ & $17.5 \mathrm{a}$ & $25.0 \mathrm{bc}$ & $6.57 \mathrm{a}$ & $124.6 \mathrm{ab}$ & $183.8 \mathrm{ab}$ & $257.4 \mathrm{ab}$ \\
\hline Control & $0.06 \mathrm{~b}$ & $4.2 \mathrm{~b}$ & $10.4 \mathrm{c}$ & $17.1 \mathrm{c}$ & $2.81 \mathrm{~b}$ & $52.7 \mathrm{~b}$ & $103.1 \mathrm{~b}$ & $152.5 b$ \\
\hline Fert & $0.10 \mathrm{ab}$ & $8.4 \mathrm{a}$ & $20.9 \mathrm{a}$ & $30.6 \mathrm{a}$ & $4.85 \mathrm{ab}$ & $164.6 \mathrm{a}$ & $288.4 \mathrm{a}$ & $383.3 \mathrm{a}$ \\
\hline \multicolumn{9}{|l|}{ Manure-1x } \\
\hline m1-y1 & $0.07 \mathrm{ab}$ & $8.0 \mathrm{a}$ & $18.2 \mathrm{ab}$ & $25.3 \mathrm{ab}$ & $3.18 \mathrm{ab}$ & $140.3 \mathrm{a}$ & 201.6ab & $268.4 \mathrm{ab}$ \\
\hline $\mathrm{m} 1-\mathrm{y} 2$ & $0.08 \mathrm{ab}$ & $4.8 \mathrm{~b}$ & $12.1 b c$ & $21.8 \mathrm{ab}$ & $3.6 \mathrm{ab}$ & $62.6 \mathrm{~b}$ & $119.4 b$ & $211.0 \mathrm{~b}$ \\
\hline m1-y3 & $0.07 \mathrm{~b}$ & $4.1 \mathrm{~b}$ & $11.7 \mathrm{bc}$ & $17.3 \mathrm{c}$ & $2.98 \mathrm{ab}$ & $56.4 \mathrm{ab}$ & $123.2 \mathrm{~b}$ & $151.4 \mathrm{~b}$ \\
\hline \multicolumn{9}{|l|}{ Manure-3x } \\
\hline m3-y1 & $0.13 \mathrm{ab}$ & $7.6 \mathrm{a}$ & $19.6 \mathrm{a}$ & $24.8 \mathrm{abc}$ & $5.89 \mathrm{ab}$ & $140.5 \mathrm{a}$ & $251.8 \mathrm{a}$ & $300.2 \mathrm{ab}$ \\
\hline $\mathrm{m} 3-\mathrm{y} 2$ & $0.13 \mathrm{ab}$ & $7.0 \mathrm{ab}$ & $18.4 \mathrm{a}$ & $25.3 \mathrm{ab}$ & $5.86 \mathrm{ab}$ & $118.6 \mathrm{ab}$ & $236.8 \mathrm{a}$ & $315.4 \mathrm{ab}$ \\
\hline m3-y3 & $0.13 \mathrm{ab}$ & $6.0 \mathrm{ab}$ & $17.3 \mathrm{a}$ & $22.7 \mathrm{~b}$ & $5.44 \mathrm{ab}$ & $92.4 \mathrm{ab}$ & $211.4 \mathrm{a}$ & $252.6 \mathrm{ab}$ \\
\hline \multicolumn{9}{|c|}{ Treatment classes for orthogonal contrasts } \\
\hline No manure & 0.10 & 6.6 & 16.2 & 24.1 & 4.7 & 114.0 & 189.4 & 262.9 \\
\hline Manure & 0.10 & 6.3 & 16.2 & 22.8 & 4.5 & 101.8 & 191.1 & 246.2 \\
\hline Manure-1x & $0.07 b$ & $5.6 \mathrm{~b}$ & $14.0 \mathrm{~b}$ & $21.5 b$ & $3.3 \mathrm{~b}$ & $86.4 \mathrm{~b}$ & $146.9 \mathrm{~b}$ & $207.6 \mathrm{~b}$ \\
\hline Manure-3x & $0.13 \mathrm{a}$ & $6.9 \mathrm{a}$ & $18.4 \mathrm{a}$ & $24.1 \mathrm{a}$ & $5.7 \mathrm{a}$ & $117.2 \mathrm{a}$ & $235.2 \mathrm{a}$ & $284.8 \mathrm{a}$ \\
\hline Manure Year-1 & 0.10 & $7.8 \mathrm{a}$ & $18.9 \mathrm{a}$ & 24.8 & 4.5 & $140.4 \mathrm{a}$ & $227.8 \mathrm{a}$ & 273.4 \\
\hline Manure Year 2 \& 3 & 0.10 & $5.5 \mathrm{~b}$ & $14.9 \mathrm{~b}$ & 21.8 & 4.5 & $82.5 \mathrm{~b}$ & $172.7 \mathrm{~b}$ & 232.6 \\
\hline Year 2 \& 3: $\mathrm{m} 1$ & $0.08 b$ & $4.5 \mathrm{~b}$ & $11.9 \mathrm{~b}$ & $19.6 \mathrm{~b}$ & $3.3 \mathrm{~b}$ & $59.5 b$ & $121.3 \mathrm{~b}$ & $181.2 \mathrm{~b}$ \\
\hline Year $2 \& 3: \mathrm{m} 3$ & $0.13 a$ & $6.5 \mathrm{a}$ & $17.85 \mathrm{a}$ & $24.0 \mathrm{a}$ & $5.65 a$ & $105.5 \mathrm{a}$ & $224.1 \mathrm{a}$ & $284.0 \mathrm{a}$ \\
\hline
\end{tabular}

${ }^{\dagger}$ NE-Fert: noneroded fertilizer (all other treatments on eroded soil); m1: manure-1x; m3: Manure-3x; y1, y2, y3: fall manure applied 1, 2, and 3 years in the past, respectively; manure: $\mathrm{m} 1+\mathrm{m} 3$; no manure: NEFert + Control + Fert.

${ }^{\ddagger}$ Within a given plant component and sample date, treatment means followed by the same lower case letter are not significantly different $(P<0.05)$. Not displayed if effect was not significant in the ANOVA (Table 5).

available soil $\mathrm{N}$ than $\mathrm{y} 2$ and $\mathrm{y} 3$ manure during the June-July sugarbeet growth period, but in later months, either soil $\mathrm{N}$ availability declined or some factor interfered with the growth and $\mathrm{N}$ uptake in yl manure beets. We hypothesize that the former was the case, resulting from increased $\mathrm{N}$ immobilization for yl beets during the June and July. The release of abundant, readily metabolized $\mathrm{C}$ from manure in y1 may have stimulated microbial growth [38, 39]. Lentz et al. [11] showed that immobilization in manure-amended soils was greater in y1 after application compared to y2 and y3 (see later discussion).

Fourth, when y1 manure treatments as a class were compared with y2 and y3 manure treatments, y1 had $1.14 \mathrm{x}$ greater season-long total biomass production and $1.18 \mathrm{x}$ greater total $\mathrm{N}$ uptake (Table 4 ). Within a manure treatment and measurement period, however, the magnitude and significance of the differences between y1 manure treatments and $y 2$ or $y 3$ manure treatments were greater and more common for manure-1x than for manure-3x treatments (Table 4). This suggests that manure- $3 \mathrm{x}$ treatments, regardless of age, provided adequate $\mathrm{N}$ for the crop. Furthermore, the $\mathrm{m} 1-\mathrm{y} 1$ treatment resulted in similar sugarbeet biomass production and $\mathrm{N}$ uptake as any manure- $3 \mathrm{x}$ treatment no matter the year applied. This indicates that the m1-y1 treatment also provided adequate $\mathrm{N}$ for the sugarbeet.

The Fert and NE-Fert treatments consistently produced greater season-long crop biomass and $\mathrm{N}$ uptake than the control, although the difference was significant only for Fert after 1 June (Table 4, Figure 2), reflecting the greater $\mathrm{N}$ availability in the two fertilized treatments compared to the control. The NE-Fert produced greater sugarbeet biomass and $\mathrm{N}$ uptake than Fert on 1 June, day of year (DOY) 152, whereas the opposite tendency was observed at later dates. This likely resulted because seedlings emerged later and stand counts were 15\% smaller (after thinning) in Fert plots relative to NE-Fert (data not presented). Later in the season, the lesser plant density for Fert compared to NE-Fert and other treatments (after thinning) may have rendered it less susceptible to a powdery mildew outbreak [40], which was identified in the field in midsummer and subsequently treated with fungicide and sulfur.

3.2. Sugarbeet Yield, Quality, and Profitability. Clean beet yields for all treatments ranged from 56.4 to $101.1 \mathrm{Mg} \mathrm{ha}^{-1}$ and averaged $83.0 \mathrm{Mg} \mathrm{ha}^{-1}$ (Table 5). These yields compare favorably with the average 2007 sugarbeet yield for southern 


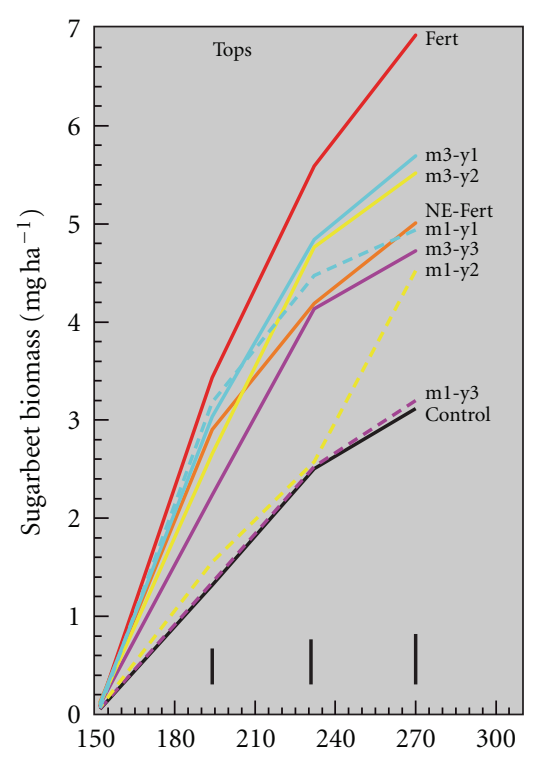

(a)

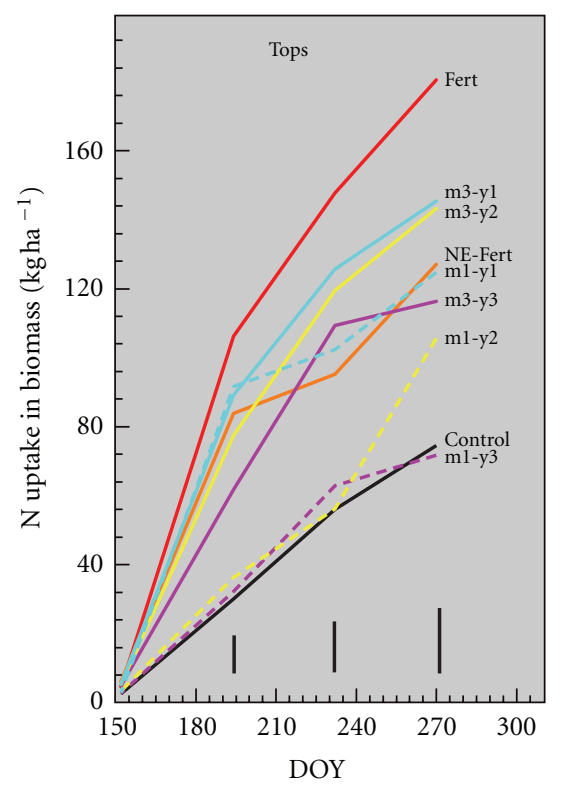

(c)

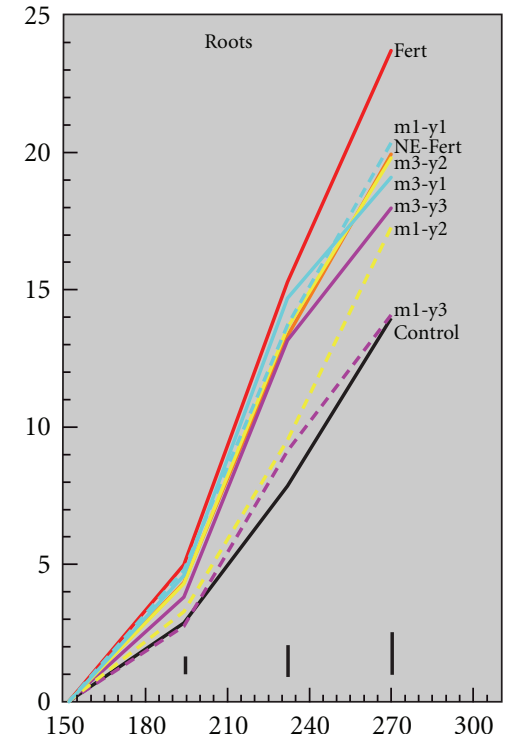

(b)

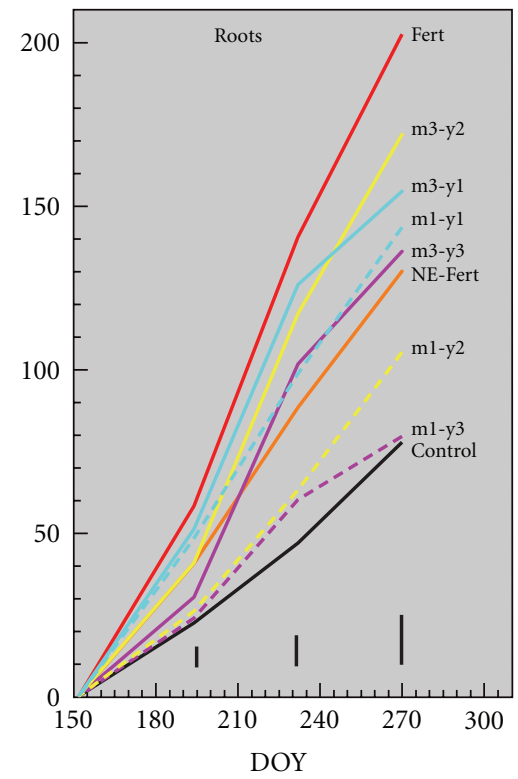

(d)

FIGURE 2: The effect of treatments on biomass accumulation in sugarbeet tops, that is, aboveground tissue (a) and root (b) components, and on $\mathrm{N}$ uptake in sugarbeet tops (c) and roots (d) in 2007. (Measured on dates (DOY) 1 June (152), 13 July (194), 20 Aug. (232), and 27 Sep. (270). Bar length represents the mean standard error $(n=4)$ for the 9 treatments at the given measurement date.

Idaho growers, $76.6 \mathrm{Mg} \mathrm{ha}^{-1}$ [36]. Sugarbeet yield and quality were affected by treatments, whether considered individually or when compared as classes (contrasts). The m1-y1, m3$\mathrm{y} 1$, and $\mathrm{m} 3-\mathrm{y} 2$ treatments produced 1.3 to 1.8 times greater root yields than NE-Fert, control, m1-y2, and m1-y3 treatments (Table 5). Contrast tests showed that yields increased about 1.2-fold when (1) manure instead of fertilizer or no amendment was added to soil; (2) the manure amendment rate was increased from $1 \mathrm{x}$ to $3 \mathrm{x}$; (3) sugarbeet was planted in the first year after fall manure application instead of waiting until the 2nd or 3rd year after application (Table 5).
Sugar concentration in beets ranged from 15.6 to $17.7 \%$ and averaged $16.7 \%$ (Table 5) with concentrations being generally greater in lower-yielding treatments, as expected. Our study's mean sugar concentration was nearly equivalent to the average sugar concentration obtained by southern Idaho growers in 2007, that is, $16.8 \%$ [36]. The NE-Fert and control treatments produced greater beet sugar concentrations than Fert, m3-y2, and m3-y3 treatments (mean 17.6 versus 16.0). Beet sugar concentrations decreased slightly (3-6\% on average) when (1) manure was applied instead of fertilizer or no amendment; (2) manure application was 
TABLE 5: Treatment and orthogonal contrast mean values for sugarbeet yield, quality, and gross margin parameters.

\begin{tabular}{|c|c|c|c|c|c|c|}
\hline \multirow[t]{2}{*}{ Treatment $^{\dagger}$} & Clean beet root yield ${ }^{\ddagger}$ & Sugar & Est. Recov. sugar ${ }^{\ddagger}$ & Brei nitrate & $\begin{array}{c}\text { Brei } \\
\text { conductivity }\end{array}$ & $\begin{array}{c}\text { Gross } \\
\text { margin }^{\S}\end{array}$ \\
\hline & $\mathrm{Mgha}^{-1}$ & $\%$ & & & & \\
\hline \multicolumn{7}{|l|}{ No manure } \\
\hline NE-Fert & $75.2 c^{\S}$ & $17.7 \mathrm{a}$ & $11.6 \mathrm{ab}$ & $59.8 \mathrm{c}$ & $0.58 \mathrm{~d}$ & $979 b c$ \\
\hline Control & $56.4 \mathrm{c}$ & $17.6 \mathrm{a}$ & $8.5 b$ & $106.8 \mathrm{c}$ & $0.68 \mathrm{~cd}$ & $292 \mathrm{~d}$ \\
\hline Fert & $90.2 \mathrm{ab}$ & $16.4 \mathrm{~b}$ & $12.3 \mathrm{ab}$ & $187.3 \mathrm{bc}$ & $0.88 \mathrm{bc}$ & $1272 \mathrm{ab}$ \\
\hline \multicolumn{7}{|l|}{ Manure-1x } \\
\hline m1-y1 & $101.0 \mathrm{a}$ & $16.7 \mathrm{ab}$ & $14.0 \mathrm{a}$ & $147.1 \mathrm{bc}$ & $0.91 b$ & $1884 a$ \\
\hline m1-y2 & $72.8 b c$ & $16.8 \mathrm{ab}$ & $10.4 \mathrm{ab}$ & $143.6 \mathrm{bc}$ & $0.77 \mathrm{bcd}$ & $731 \mathrm{bcd}$ \\
\hline $\mathrm{m} 1-\mathrm{y} 3$ & $64.5 c$ & $16.8 \mathrm{ab}$ & $9.1 \mathrm{~b}$ & $185.4 \mathrm{bc}$ & $0.81 \mathrm{bc}$ & $484 \mathrm{~cd}$ \\
\hline \multicolumn{7}{|l|}{ Manure-3x } \\
\hline m3-y1 & $97.7 \mathrm{a}$ & $16.8 \mathrm{ab}$ & $13.6 \mathrm{a}$ & $149.1 \mathrm{bc}$ & $0.95 b$ & $1676 a$ \\
\hline m3-y2 & $101.1 \mathrm{a}$ & $16.0 \mathrm{~b}$ & $13.2 \mathrm{a}$ & 259.6ab & $0.96 b$ & $1510 \mathrm{ab}$ \\
\hline m3-y3 & $88.5 \mathrm{ab}$ & $15.6 \mathrm{~b}$ & $11.2 \mathrm{ab}$ & $308.5 a$ & $1.02 \mathrm{a}$ & $1138 \mathrm{~b}$ \\
\hline \multicolumn{7}{|c|}{ Treatment classes for contrasts } \\
\hline No manure & $73.9 b$ & $17.2 \mathrm{a}$ & 10.8 & $118.0 \mathrm{~b}$ & $0.71 \mathrm{a}$ & $848 b$ \\
\hline Manure & $87.6 a$ & $16.5 b$ & 11.9 & $198.9 \mathrm{a}$ & $0.90 \mathrm{~b}$ & $1237 \mathrm{a}$ \\
\hline Manure-1x & $79.4 \mathrm{~b}$ & $16.8 \mathrm{a}$ & $11.2 \mathrm{~b}$ & $158.7 \mathrm{~b}$ & $0.83 \mathrm{~b}$ & $1033 b$ \\
\hline Manure-3x & $95.8 \mathrm{a}$ & $16.1 \mathrm{~b}$ & $12.7 \mathrm{a}$ & 239.1a & $0.98 \mathrm{a}$ & $1441 \mathrm{a}$ \\
\hline Manure y1 & $99.4 \mathrm{a}$ & $16.8 \mathrm{a}$ & $13.8 \mathrm{a}$ & $148.1 \mathrm{~b}$ & 0.93 & $1780 \mathrm{a}$ \\
\hline Manure y2 \& y3 & $81.7 \mathrm{~b}$ & $16.3 \mathrm{~b}$ & $11.0 \mathrm{~b}$ & $224.3 \mathrm{a}$ & 0.89 & $966 b$ \\
\hline Year 2 \& 3: m1 & $68.7 b$ & $16.8 \mathrm{a}$ & $9.8 \mathrm{~b}$ & $164.5 b$ & $0.79 b$ & $607 b$ \\
\hline Year 2 \& 3: m3 & $94.8 \mathrm{a}$ & $15.8 \mathrm{~b}$ & $12.2 \mathrm{a}$ & 284.1a & $0.99 a$ & $1324 a$ \\
\hline m1-y1, m3-y1, m3-y2 & $99.9 a$ & $16.5 b$ & $13.6 \mathrm{a}$ & 185.3 & $0.9 \mathrm{a}$ & $1690 \mathrm{a}$ \\
\hline NE-Fert, Fert & $82.7 \mathrm{~b}$ & $17.1 \mathrm{a}$ & $12.0 \mathrm{~b}$ & 123.6 & $0.7 \mathrm{~b}$ & $1126 b$ \\
\hline
\end{tabular}

${ }^{\dagger}$ NE-Fert: noneroded fertilizer (all other treatments on eroded soil); m1: manure-1x; m3: manure-3x; y1, y2, y3: fall manure applied 1, 2, and 3 years in the past, respectively; manure: $\mathrm{m} 1+\mathrm{m} 3$; no manure: NEFert + Control + Fert.

${ }^{\ddagger}$ Clean yield: yield minus soil tare; Est. Recov. Sugar: estimated amount of sugar extractable from beets per unit area.

$\S$ Gross margin: gross revenue minus operating costs.

१For a given yield or quality parameter, treatment means or means for individual orthogonal contrasts followed by the same lower case letter are not significantly different $(P<0.05)$. Not displayed if effect was not significant in the ANOVA.

increased from $1 \mathrm{x}$ to $3 \mathrm{x}$; or (3) sugarbeet was planted in the first year after fall manure application instead of waiting until the 2 nd or 3 rd year after application. These results are consistent with the concept that increasing $\mathrm{N}$ availability decreases beet root sugar concentration $[8,9]$.

Increased nitrate and soluble impurity (conductivity) concentrations in sugarbeet brei (fresh macerated beet root) are associated with a decrease in the quantity of sugar recovered from the sugarbeet and increased sugar extraction costs $[4,27]$. When the manure application rate increased from $1 \mathrm{x}$ to $3 \mathrm{x}$, brei nitrate increased an average 1.6-fold (from 158.7 to $239 \mathrm{mg} \mathrm{kg}^{-1}$ ) and conductivity increased 1.2 -fold on average. Brei conductivity of manure treatments in year 1 did not differ from the mean value for year 2 and year 3 . The m3-y3 treatment produced the greatest brei nitrate concentrations in beet roots, $309 \mathrm{mg} \mathrm{kg}^{-1}$. While this value exceeded the $250 \mathrm{mg} \mathrm{kg}^{-1}$ target level recommended for southern Idaho [27], it was still well below the mean value for the 2007, southcentral Idaho sugarbeet crop, $351 \mathrm{mg} \mathrm{kg}^{-1}$ (S. Camp, Amalgamated Sugar Co., personal communication, 2010).
The control produced the least estimated recoverable sugar, $8.5 \mathrm{Mg} \mathrm{ha}^{-1}$ (Table 5). The treatments m1-y1, m3-y1, and $\mathrm{m} 3-\mathrm{y} 2$ produced the greatest estimated recoverable sugar values (mean $13.6 \mathrm{Mgha}^{-1}$ ), which were $1.5 \mathrm{x}$ greater than that of the two least performing treatments, $\mathrm{m} 1-\mathrm{y} 3$ and control (mean $8.8 \mathrm{Mgha}^{-1}$ ), and $1.1 \mathrm{x}$ that of the two fertilizer treatments (mean $12.0 \mathrm{Mg} \mathrm{ha}^{-1}$ ). In addition, the estimated recoverable sugar in beets increased 1.22-fold, on average, when manure application was increased from the $1 \mathrm{x}$ to $3 \mathrm{x}$ rate or sugarbeet was planted in the first year after fall manure application instead of waiting until the 2 nd or 3 rd year after application.

The gross margins listed in Table 5 integrate treatment effects on beet yield and quality and fertilizer or manure costs, and provide a measure of treatment effects on profitability. An examination of individual manure treatments revealed that all except m1-y3 produced similar or greater gross margins than either the Fert or NE-Fert. Contrast tests showed that 1 ) the average gross margin for $\mathrm{m} 1-\mathrm{y} 1$, $\mathrm{m} 3-\mathrm{y} 1$, and $\mathrm{m} 3-\mathrm{y} 2$ manure treatments was 1.5 -fold greater 
TABle 6: Treatment and contrast class mean values for soil $(0-30 \mathrm{~cm})$ inorganic $\mathrm{N}$ concentrations in spring (before and after planting), cumulative net $\mathrm{N}$ mineralization, and cumulative available $\mathrm{N}$ during the growing season.

\begin{tabular}{|c|c|c|c|c|}
\hline Treatment $^{\dagger}$ & $\begin{array}{l}\text { Soil N } \\
15 \text { Mar. }\end{array}$ & $\begin{array}{l}\text { Soil N } \\
25 \text { Apr. }\end{array}$ & $\begin{array}{c}\text { Cum. net } \mathrm{N} \text { mineralized } \\
25 \mathrm{Apr}-27 \text { Sept. } \\
\mathrm{mg} \mathrm{kg}^{-1}\end{array}$ & $\begin{array}{l}\text { Cum. available N } \\
15 \text { Mar.-27 Sept. }\end{array}$ \\
\hline \multicolumn{5}{|l|}{ No manure } \\
\hline NE-Fert & $8.3 \mathrm{~b}^{\ddagger}$ & $39.0 \mathrm{a}$ & $18.0 \mathrm{bc}$ & $57.0 \mathrm{bc}$ \\
\hline Control & $10.9 \mathrm{~b}$ & $12.6 b$ & $14.6 \mathrm{c}$ & $27.1 \mathrm{~d}$ \\
\hline Fert & $8.9 b$ & $33.6 \mathrm{a}$ & $19.6 \mathrm{bc}$ & $62.8 \mathrm{bc}$ \\
\hline \multicolumn{5}{|l|}{ Manure-1x } \\
\hline m1-y1 & $13.5 b$ & $31.8 \mathrm{a}$ & $32.8 \mathrm{ab}$ & $64.6 \mathrm{~b}$ \\
\hline $\mathrm{m} 1-\mathrm{y} 2$ & $10.0 \mathrm{~b}$ & $17.9 \mathrm{~b}$ & $23.7 \mathrm{bc}$ & $41.6 \mathrm{c}$ \\
\hline m1-y3 & $8.3 b$ & $14.1 \mathrm{~b}$ & $22.5 b c$ & $36.7 \mathrm{~cd}$ \\
\hline \multicolumn{5}{|l|}{ Manure-3x } \\
\hline m3-y1 & $24.1 \mathrm{a}$ & $45.9 \mathrm{a}$ & $41.4 \mathrm{a}$ & $87.3 \mathrm{a}$ \\
\hline m3-y2 & $12.7 \mathrm{~b}$ & $27.8 \mathrm{ab}$ & $28.5 b c$ & $56.3 \mathrm{bc}$ \\
\hline m3-y3 & $13.7 \mathrm{~b}$ & $28.7 \mathrm{ab}$ & $29.1 \mathrm{~b}$ & $57.8 \mathrm{bc}$ \\
\hline \multicolumn{5}{|c|}{ Treatment classes for contrasts } \\
\hline No manure & 9.4 & 28.4 & $17.1 \mathrm{~b}$ & $49.0 \mathrm{~b}$ \\
\hline Manure & 13.7 & 27.7 & $29.7 \mathrm{a}$ & $57.4 \mathrm{a}$ \\
\hline Manure-1x & 10.6 & $21.3 b$ & $26.3 \mathrm{~b}$ & $47.6 \mathrm{~b}$ \\
\hline Manure-3x & 16.8 & $34.1 \mathrm{a}$ & $32.9 \mathrm{a}$ & $67.1 \mathrm{a}$ \\
\hline Manure yl & 18.8 & $38.9 \mathrm{a}$ & $37.1 \mathrm{a}$ & $76.0 \mathrm{a}$ \\
\hline Manure y2 \& y3 & 11.2 & $22.1 \mathrm{~b}$ & $26.0 \mathrm{~b}$ & $48.1 \mathrm{~b}$ \\
\hline Year 2 \& 3: m1 & $9.2 \mathrm{~b}$ & $16.0 \mathrm{~b}$ & $23.1 \mathrm{~b}$ & $39.2 b$ \\
\hline Year $2 \& 3: \mathrm{m} 3$ & $13.2 \mathrm{a}$ & $28.3 \mathrm{a}$ & $28.8 \mathrm{a}$ & $57.1 \mathrm{a}$ \\
\hline
\end{tabular}

${ }^{\dagger}$ NE-Fert: noneroded fertilizer (all other treatments on eroded soil); m1: manure-1x; m3: manure-3x; y1, y2, y3: fall manure applied 1, 2, and 3 years in the past, respectively; manure: $\mathrm{m} 1+\mathrm{m} 3$; No manure: NEFert + Control + Fert.

${ }^{\ddagger}$ For a given yield or quality parameter, treatment means or means for individual orthogonal contrasts followed by the same lower case letter are not significantly different $(P<0.05)$. Not displayed if effect was not significant in the ANOVA.

than that for NE-fert and Fert treatments; 2) manure-3x treatments as a whole produced 1.4 -fold greater gross margin than manure- $1 \mathrm{x}$ treatments; 3 ) the mean gross margin for $\mathrm{y} 1$ manure treatment class was 1.8 -fold greater than the $y 2$ and y3 manure mean value; and 4) in the 2nd and 3rd year after manure application the manure-3x treatments on average resulted in a 2.2-fold greater gross margin than the manure$1 \mathrm{x}$ treatments.

Thus, fall manure applications 1 or 2 years prior to growing sugarbeet can potentially widen profit margins relative to conventional fertilizers applied preplant in the spring. While the m1-y1 manure treatment produced the greatest mean gross margin, use of greater manure application rates might be advisable. Manure quality often varies and the $1 \mathrm{x}$ rate leaves less margin for error. A greater application rate every two years, rather than one, halves application costs. Moreover, a high $\mathrm{N}$-demand crop such as corn could be grown the year before sugarbeet to efficiently and profitably use the $\mathrm{N}$ mineralized in the first 12 months after the manure was applied [11]. On the other hand, mineralized $\mathrm{N}$ (as $\mathrm{NO}_{3}{ }^{-}$) could be leached below the sugarbeet's root zone before or during the beet growing season. Note that our margin analysis does not account for extra costs that may arise due to manure use, for example, additional management costs associated with increased weed pressure.

The influence of increasing manure applications on sugarbeet yields and estimated recoverable sugar in year 1 were also investigated by Lentz et al. [11] in 2003 for similar soils in southern Idaho. Lentz et al. [11] reported that, in contrast to the results of this study, sugarbeet root yields and recoverable sugar decreased as manure application rates increased. This difference was likely due to less initial residual soil $\mathrm{N}$ and less $\mathrm{C}$ and total $\mathrm{N}$ in the manure used in the current study relative to those in 2003. In sum, these factors decreased the $\mathrm{N}$ available in the 2007 soils which in turn reduced the possibility that excessive $\mathrm{N}$ mineralized from manure amendments would limit beet yields and recoverable sugar values $[2,8]$.

3.3. $N$ Mineralization and Availability. The contrast tests for the season-long (25 Apr. to 27 Sept.) cumulative net $\mathrm{N}$ mineralization (Table 6) established that (1) manure treatments taken as a class produced $1.7 \mathrm{x}$ greater $\mathrm{N}$ than nomanure treatments; (2) manure- $3 \mathrm{x}$ treatments on average produced $1.3 \mathrm{x}$ greater $\mathrm{N}$ than manure- $1 \mathrm{x}$ treatments; (3) $\mathrm{N}$ 


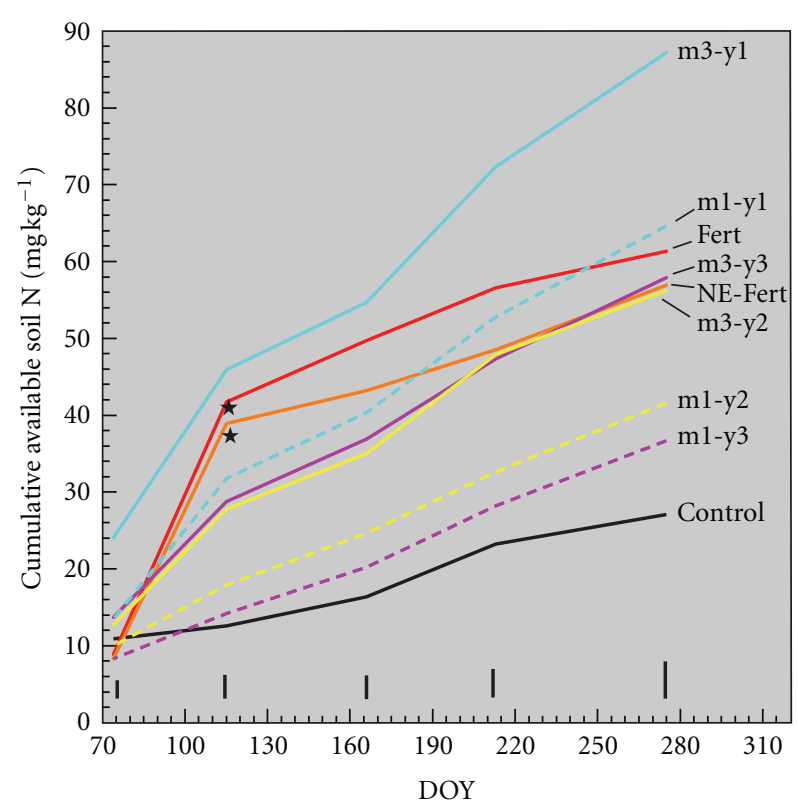

$\star$ Includes added fertilizer $\mathrm{N}$

FIGURE 3: Cumulative net soil $\mathrm{N}$ available through mineralization and any fertilizer addition in the 0 -to- $30 \mathrm{~cm}$ soil during the 2007 sugarbeet growing season (measured on dates (DOY) 15 Mar. (74), 25 Apr. (115), 15 June (166), 1 Aug. (213), and 2 Oct. (275). Bar length represents the mean standard error $(n=4)$ for the 9 treatments at the given measurement date.

mineralized from $\mathrm{y} 1$ manure treatments as a class was $1.4 \mathrm{x}$ greater than that for the $\mathrm{y} 2$ and $\mathrm{y} 3$ manure treatment class mean. Hence, the cumulative available soil $\mathrm{N}$ from manure amendments generally declined as application rate decreased and time since application increased (Table 6, Figure 3 ).

The net $\mathrm{N}$ mineralized in the uppermost $0.3 \mathrm{~m}$ soil profile during the growing season (25 Apr. to $27 \mathrm{Sept}$.) for year-1 manure treatments was $32.8 \mathrm{mg} \mathrm{kg}^{-1}$ for manure- $1 \mathrm{x}$, or 2.2 times the control value, and $41.4 \mathrm{mg} \mathrm{kg}^{-1}$ for manure-3x, or 2.8 times that of the control (Table 6). These net $\mathrm{N}$ mineralization values for the year- 1 treatments were similar to those reported by Lentz et al. [11] for comparable treatments in 2003, that is, 32.6 (manure-1x) and $48.7 \mathrm{mg} \mathrm{kg}^{-1}$ (manure-3x). Net $\mathrm{N}$ mineralized during the growing season for year- 2 and year- 3 manure treatments was reduced an average $30 \%$ in comparison to year- 1 manure (Table 6). Findings from the 2007 growing season showed that fertilizer and the m1-y1, m3-y2, and $\mathrm{m} 3-\mathrm{y} 3$ treatments supplied similar amounts of cumulative N. In contrast m3y1 provided nearly $1.5 \mathrm{x}$ more $\mathrm{N}(P<0.0001)$, and $\mathrm{m} 1-\mathrm{y} 2$ and $\mathrm{m} 1-\mathrm{y} 3$ provided $37 \%$ less $\mathrm{N}(P<0.0001)$ than the mean fertilizer treatment value (Table 6, Figure 3). The control and $\mathrm{m} 1-\mathrm{y} 3$ treatments provided the least cumulative available soil $\mathrm{N}$, produced the least biomass, and led to the least $\mathrm{N}$ being incorporated into crop tissue (Figures 2 and 3 ).

For manure treatments, mineralized $\mathrm{N}$ accumulated at a slower rate in the interval from 25 Apr. to 15 June (DOY 115 to 166) than for other intervals (revealed as a decrease in slope in Figure 3). This slowing of the rate was most pronounced for the larger and more recent manure applications. This corroborates observations made by Lentz et al. [11], who described an identical phenomenon in their experiment conducted on similar soils at Kimberly, ID. The slowing rate of net $\mathrm{N}$ mineralization was likely due to immobilization of manure $\mathrm{N}$ that occurred after soils warmed during this early summer period. Mean soil temperatures at the $10 \mathrm{~cm}$ depth exceeded $21^{\circ} \mathrm{C}$ by mid-June (data not shown). Seasonal $\mathrm{N}$ mineralization data from an Ontario, Canada, experiment also showed a subtle dip in mineralization rate during this period, but the researchers described a more substantial decrease in N mineralization rate after DOY 227 [15]. The researchers attributed the substantial decreases to the release of carbonaceous root exudates and subsequent $\mathrm{N}$ immobilization [15]. Similar declines in $\mathrm{N}$ mineralization during the early summer period were reported for coastal Alabama soils amended with composted dairy manure [41].

The pattern of crop biomass accumulation and N-uptake in sugarbeet tops and roots (Figure 2) generally followed that of soil $\mathrm{N}$ availability (Figure 3 ). There were two exceptions. First, while Fert and NE-Fert treatments provided similar soil N, Fert produced substantially greater season-long crop biomass and $\mathrm{N}$ uptake than the NE-Fert (Figure 2, Table 4). This may be related to the differences in stand density and mildew pathology, as discussed previously. Second, though the net $\mathrm{N}$ mineralized for the $\mathrm{m} 3$ treatment was greater in $\mathrm{y} 1$ than for $\mathrm{y} 2$ or $\mathrm{y} 3$ (Figure 3), the extra $\mathrm{N}$ mineralized in y1 did not result in greater season-long crop $\mathrm{N}$ uptake (Figure 2, Table 4). This reveals that the $\mathrm{N}$ derived from the $3 \mathrm{x}$ manure (applied in the previous fall) was not utilized efficiently, presumably because it exceeded crop needs. Moreover, the excess soil mineral $\mathrm{N}$ in the $3 \mathrm{x}$ treatments was subject to leaching losses.

\section{Conclusions}

This study quantifies the effects of stock-piled dairy manure applications made 1, 2, or 3 years previously on sugarbeet. Results of this and a previous, related study [11] on calcareous, southern Idaho soil indicate that the influence of manure $\mathrm{N}$ applications on soil $\mathrm{N}$ availability, $\mathrm{N}$ uptake, and sugarbeet yield and quality was a function of residual inorganic soil $\mathrm{N}$ at the start of the growing season, the amount of Fall-applied manure added, and the year in which the manure was applied. A Fall manure application alone, when applied at an appropriate rate and planted to sugarbeet in either the first or second year after application provided adequate $\mathrm{N}$ nutrition for the production of a high quality sugarbeet crop. Furthermore, these manure treatments (m1$\mathrm{y} 1, \mathrm{~m} 3-\mathrm{y} 1$, and $\mathrm{m} 3-\mathrm{y} 2$ ) increased estimated recoverable sugar yields an average of 1.1-fold and increased gross margins an average of 1.5 -fold relative to conventional fertilizer treatments. The increases in recoverable sugar and gross margins documented in this study are likely to vary from one site to another as a function of soil type, climate, and growing conditions. Our results illustrate nonetheless how proper manure management can increase sugarbeet yields and producer profit margins. 


\section{Abbreviations}

Fert: $\quad$ Fertilizer on eroded soil

NE-Fert: Fertilizer on noneroded soils

EC: $\quad$ Electrical conductivity

y1, y2, y3: Fall manure applied 1, 2, and 3 years in the past, respectively.

\section{References}

[1] C. W. Robbins, B. E. Mackey, and L. L. Freeborn, "Improving exposed subsoils with fertilizers and crop rotations," Soil Science Society of America Journal, vol. 61, no. 4, pp. 1221-1225, 1997.

[2] J. N. Carter, D. T. Westermann, and M. E. Jensen, "Sugarbeet yield and quality as affected by nitrogen level," Agronomy Journal, vol. 68, no. 1, pp. 49-55, 1976.

[3] R. Gardner and D. W. Robertson, "Comparison of the effects of manures and commercial fertilizers on the yield of sugar beets," Proceedings American Society of Sugar Beet Technology, vol. 4, pp. 27-32, 1946.

[4] A. P. Draycott and D. R. Christenson, Nutrients for Sugarbeet Production: Soil Plant Relationships, CABI Publishing, Cambridge, Mass, USA, 2003.

[5] A. D. Halvorson and G. P. Hartman, "Long-term nitrogen rates and sources influence sugarbeet yield and quality," Agronomy Journal, vol. 67, pp. 389-393, 1975.

[6] J. N. Carter, "Effect of nitrogen and irrigation levels, location and year on sucrose concentration of sugarbeets in Southern Idaho," Journal of the American Society of Sugar Beet Technologists, vol. 21, no. 3, pp. 286-306, 1982.

[7] F. J. Hills, F. E. Broadbent, and O. A. Lorenz, "Fertilizer nitrogen utilization by corn, tomato, and sugarbeet," Agronomy Journal, vol. 75, pp. 423-426, 1983.

[8] J. N. Carter and D. J. Traveller, "Effect of time and amount of nitrogen uptake on sugarbeet growth and yield," Agronomy Journal, vol. 73, pp. 665-671, 1981.

[9] F. N. Anderson and G. A. Peterson, "Effect of incrementing nitrogen application on sucrose yield of sugarbeet," Agronomy Journal, vol. 80, pp. 709-712, 1988.

[10] J. G. Davis and D. G. Westfall, "Fertilizing sugar beets," Colorado State University Cooperative Extension Fact Sheet No. 0.542, Colorado State University, Fort Collins, Colo, USA, 2010.

[11] R. D. Lentz, G. A. Lehrsch, B. Brown, J. Johnson-Maynard, and A. B. Leytem, "Dairy manure nitrogen availability in eroded and noneroded soil for sugarbeet followed by small grains," Agronomy Journal, vol. 103, pp. 628-643, 2011.

[12] E. M. Hansen, I. K. Thomsen, and M. N. Hansen, "Optimizing farmyard manure utilization by varying the application time and tillage strategy," Soil Use and Management, vol. 20, no. 2, pp. 173-177, 2004.

[13] J. J. Miller, B. W. Beasley, C. F. Drury, and B. J. Zebarth, "Barley yield and nutrient uptake for soil amended with fresh and composted cattle manure," Agronomy Journal, vol. 101, no. 5, pp. 1047-1059, 2009.

[14] E. B. Mallory, T. S. Griffin, and G. A. Porter, "Seasonal nitrogen availability from current and past applications of manure," Nutrient Cycling in Agroecosystems, vol. 88, no. 3, pp. 351-360, 2010.

[15] B. L. Ma, L. M. Dwyer, and E. G. Gregorich, "Soil nitrogen amendment effects on nitrogen uptake and grain yield of maize," Agronomy Journal, vol. 91, no. 4, pp. 650-656, 1999.
[16] B. Gagnon, R. R. Simard, R. Robitaille, M. Goulet, and R. Rioux, "Effect of composts and inorganic fertilizers on spring wheat growth and N uptake," Canadian Journal of Soil Science, vol. 77, no. 3, pp. 487-495, 1997.

[17] V. R. Kanneganti and S. D. Klausner, "Nitrogen recovery by orchard grass from dairy manure applied with or without fertilizer nitrogen," Communications in Soil Science and Plant Analysis, vol. 25, no. 15-16, pp. 2771-2781, 1994.

[18] P. P. Motavalli, K. A. Kelling, and J. C. Converse, "First-year nutrient availability from injected dairy manure," Journal of Environmental Quality, vol. 18, no. 2, pp. 180-185, 1989.

[19] B. Eghball and J. F. Power, "Phosphorus- and nitrogen-based manure and compost applications: corn production and soil phosphorus," Soil Science Society of America Journal, vol. 63, no. 4, pp. 895-901, 1999.

[20] T. S. Griffin, Z. He, and C. W. Honeycutt, "Manure composition affects net transformation of nitrogen from dairy manures," Plant and Soil, vol. 273, no. 1-2, pp. 29-38, 2005.

[21] E. B. Mallory and T. S. Griffin, "Impacts of soil amendment history on nitrogen availability from manure and fertilizer," Soil Science Society of America Journal, vol. 71, no. 3, pp. 964973, 2007.

[22] R. Xie and A. F. Mackenzie, "Urea and manure effects on soil nitrogen and corn dry matter yields," Soil Science Society of America Journal, vol. 50, no. 6, pp. 1504-1509, 1986.

[23] G. Wen, J. J. Schoenau, J. L. Charles, and S. Inanaga, "Efficiency parameters of nitrogen in hog and cattle manure in the second year following application," Journal of Plant Nutrition and Soil Science, vol. 166, no. 4, pp. 490-498, 2003.

[24] T. B. Parkin, T. C. Kaspar, and C. Cambardella, "Oat plant effects on net nitrogen mineralization," Plant and Soil, vol. 243, no. 2, pp. 187-195, 2002.

[25] S. D. Klausner, V. R. Kanneganti, and D. R. Bouldin, "An approach for estimating a decay series for organic nitrogen in animal manure," Agronomy Journal, vol. 86, no. 5, pp. 897903, 1994.

[26] G. A. Lehrsch and D. C. Kincaid, "Sprinkler irrigation effects on infiltration and near-surface unsaturated hydraulic conductivity," Transactions of the ASABE, vol. 53, no. 2, pp. 397-404, 2010.

[27] A. Moore, J. Stark, B. Brown, and B. Hopkins, "Southern Idaho fertilizer guide: sugar beets," CIS 1174, University of Idaho Extension, Idaho, Moscow, 2009.

[28] B. Eghball, B. J. Wienhold, J. E. Gilley, and R. A. Eigenberg, "Mineralization of manure nutrients," Journal of Soil and Water Conservation, vol. 57, no. 6, pp. 470-473, 2002.

[29] J. L. Wright, D. T. Westermann, and G. A. Lehrsch, "Studying nitrate- $\mathrm{N}$ leaching with a bromide tracer in an irrigated silt loam soil," in Best Management Practices for Irrigated Agriculture and the Environment, J. Schaack, A. W. Freitag, and S. S. Anderson, Eds., pp. 229-242, U.S. Committee on Irrigation and Drainage, Denver, Colo, USA, 1998, Proceedings of the Irrigation and Drainage Water Management Conference, Fargo, ND, USA, 1997.

[30] P. Patterson, The economics of growing sugarbeets in southern Idaho: a short run gross margin analysis. AEES No 09-01, US Department of Agricultural Economics and Rural Sociology, University of Idaho Extension, 2009, http://www.amalgamatedsugar.com/articles/SugarbeetPacket.pdf.

[31] K. S. Balkcom, A. M. Blackmer, and D. J. Hansen, "Measuring soil nitrogen mineralization under field conditions," Communications in Soil Science and Plant Analysis, vol. 40, no. 7-8, pp. 1073-1086, 2009. 
[32] C. F. Eno, "Nitrate production in the field by incubating the soil in polyethylene bags," Soil Science Society Of America Proceedings, vol. 24, no. 4, pp. 277-279, 1960.

[33] S. R. Olsen, C. V. Cole, F. S. Watatanabe, and L. A. Dean, "Estimation of available phosphorus in soils by extraction with sodium bicarbonate," USDA Circ. 939, U.S. Government Printing Office, Washington, DC, USA, 1954.

[34] J. J. Schoenau and R. E. Karamanos, "Sodium bicarbonateextractable P, K, and N," in Soil Sampling and Methods of Analysis, M. R. Carter, Ed., pp. 51-58, Lewis Publishers, Boca Raton, Fla, USA, 1993.

[35] SAS Institute Inc., SAS Online Documentation, Version 9.2 [CD-ROM], SAS Institute, Inc., Cary, NC, USA, 2009.

[36] S. Kraus, "Beet growers enjoy record yields," Ag Weekly, p. 29, 2007.

[37] R. D. Lentz and G. A. Lehrsch, "Net nitrogen mineralization from past year's manureand fertilizer applications," Soil Science Society of America Journal. In press, https://www.soils .org/publications/sssaj/view/76-3/s11-0282-6-4-23-2012.pdf.

[38] B. C. Liang, E. G. Gregorich, M. Schnitzer, and H.-R. Schulten, "Characterization of water extracts of two manures and their adsorption on soils," Soil Science Society of America Journal, vol. 60, no. 6, pp. 1758-1763, 1996.

[39] B. Marschner and K. Kalbitz, "Controls of bioavailability and biodegradability of dissolved organic matter in soils," Geoder$m a$, vol. 113, no. 3-4, pp. 211-235, 2003.

[40] J. J. Burdon and G. A. Chilvers, "Host density as a factor in plant disease ecology," Annual Review of Phytopathology, vol. 20, pp. 143-166, 1982.

[41] D. B. Watts, H. A. Torbert, and S. A. Prior, "Soil property and landscape position effects on seasonal nitrogen mineralization of composted dairy manure," Soil Science, vol. 175, no. 1, pp. 27-35, 2010. 


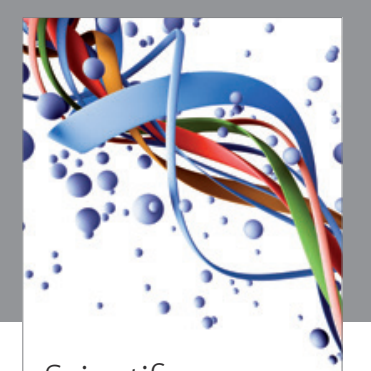

Scientifica
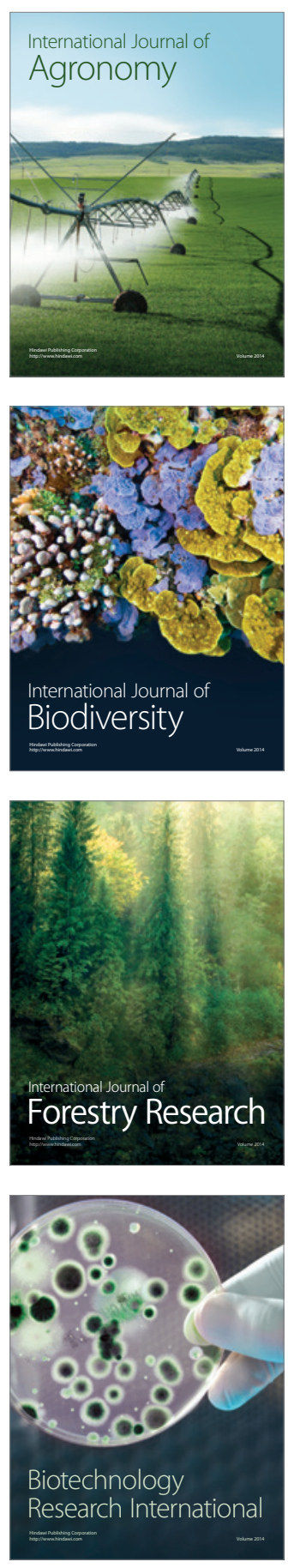
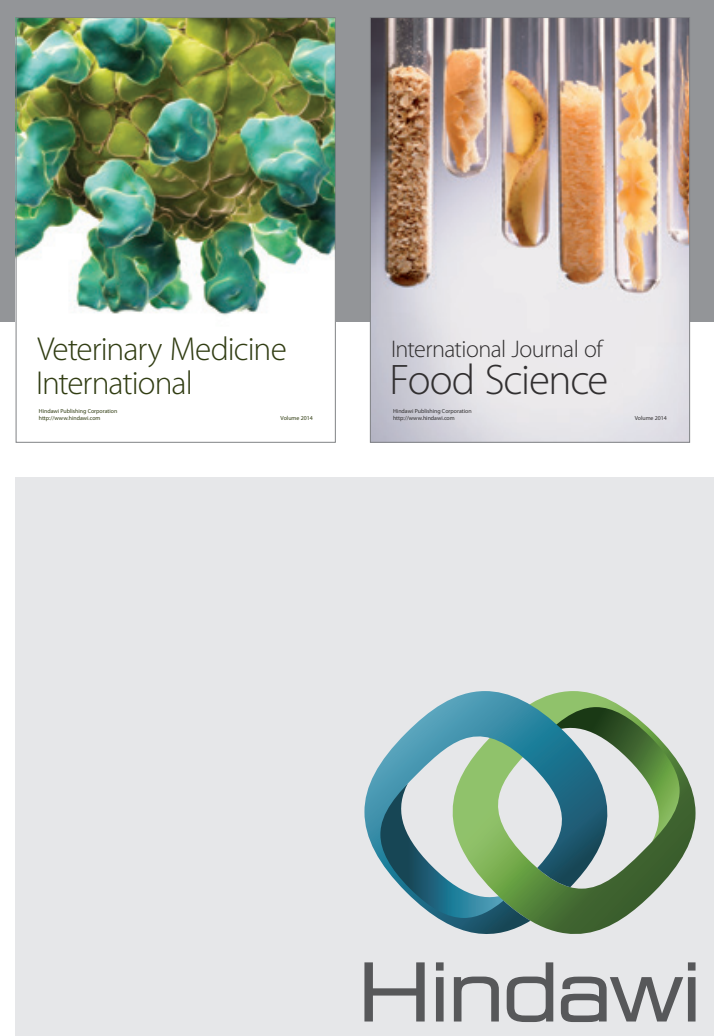

Submit your manuscripts at

http://www.hindawi.com
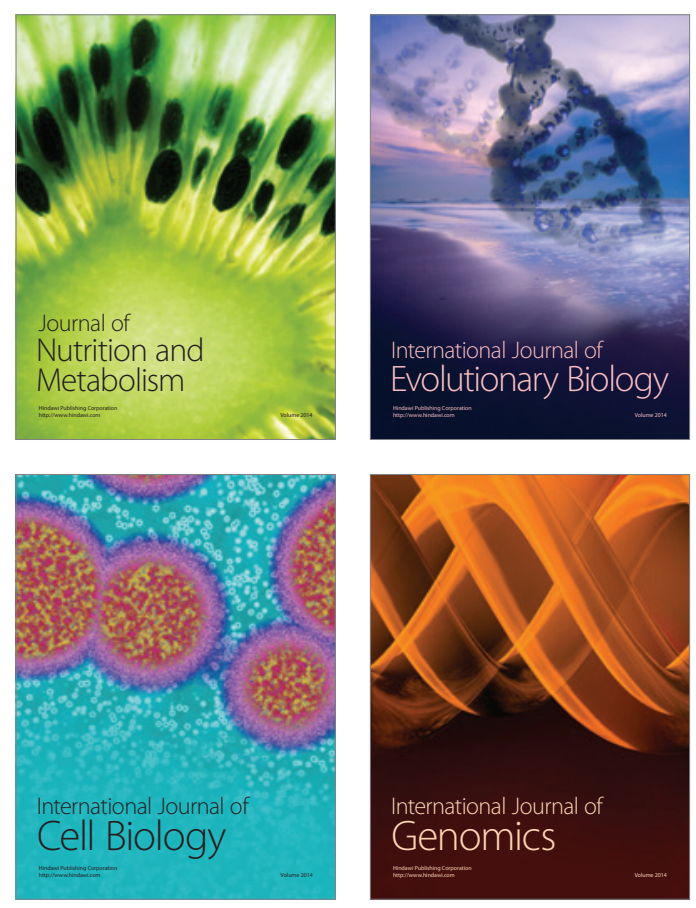
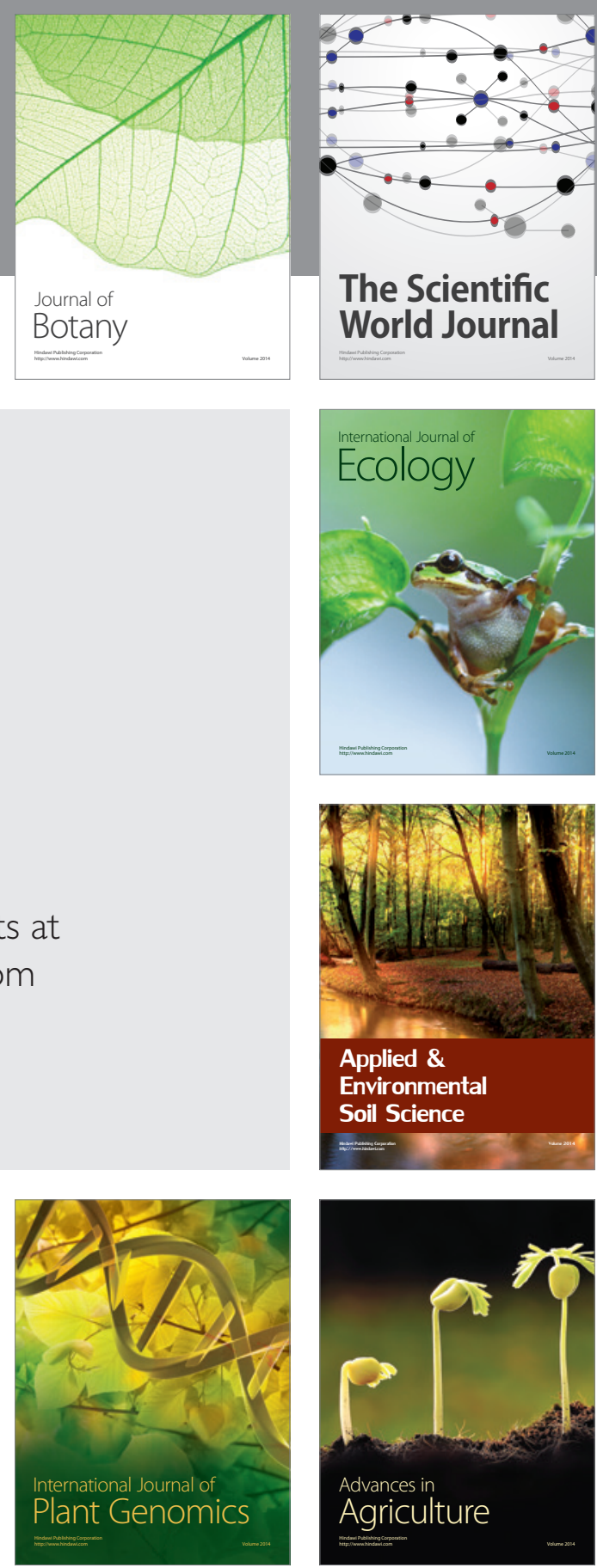

The Scientific World Journal
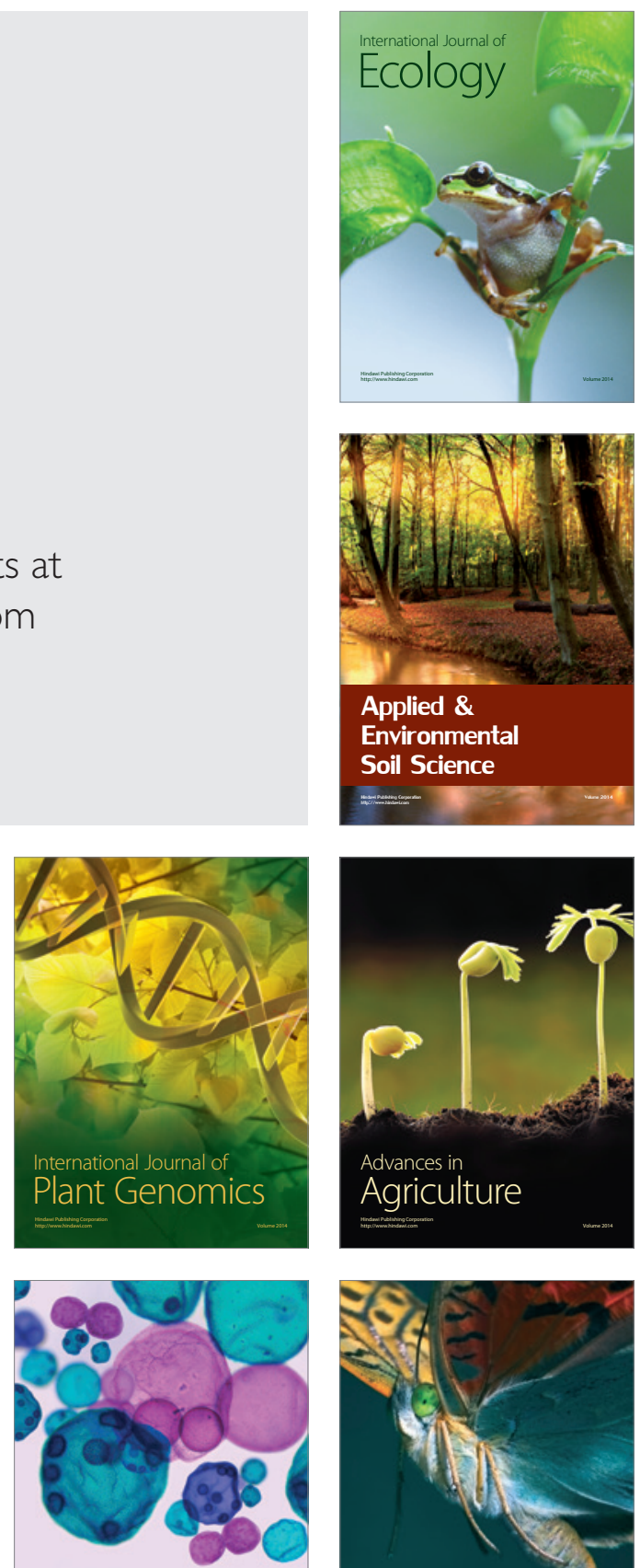

International Journal of Microbiology

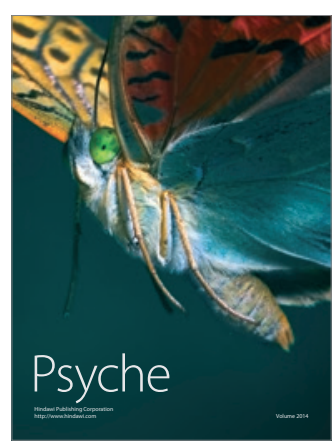

